\title{
Erratum: Case Report: Sellar Ependymomas: A Clinic-Pathological Study and Literature Review
}

\section{OPEN ACCESS}

Approved by:

Frontiers Editorial Office,

Frontiers Media SA, Switzerland

*Correspondence:

Frontiers Editorial Office

production.office@frontiersin.org

Specialty section:

This article was submitted to

Cancer Endocrinology,

a section of the journal

Frontiers in Endocrinology

Received: 28 July 2021

Accepted: 28 July 2021

Published: 02 September 2021

Citation:

Frontiers Editorial Office (2021)

Erratum: Case Report:

Sellar Ependymomas: A Clinic-Pathological Study

and Literature Review.

Front. Endocrinol. 12:748952. doi: 10.3389/fendo.2021.748952
Frontiers Editorial Office*

Frontiers Media SA, Lausanne, Switzerland

Keywords: diagnosis, ependymoma, molecular subtype, pituitary tumor, sellar ependymoma, treatment

\section{An Erratum On}

Case Report: Sellar Ependymomas: A Clinic-Pathological Study and Literature Review By Zhao L, Jiang Y, Wang Y, Bai Y, Liu L and Li Y (2021). Front. Endocrinol. 12:551493. doi: $10.3389 /$ fendo.2021.551493

Due to a production error, the first three authors were listed as co-first authors. The correct author list appears below.

The publisher apologizes for this mistake.

Liyan Zhao ${ }^{1}$, Yining Jiang ${ }^{2}$, Yubo Wang ${ }^{2}$, Yang $\mathrm{Bai}^{2}$, Liping $\mathrm{Liu}^{1}$ and Yunqian $\mathrm{Li}^{2 \star}$

The original version of this article has been updated.

Copyright ( 12021 Frontiers Editorial Office. This is an open-access article distributed under the terms of the Creative Commons Attribution License (CC BY). The use, distribution or reproduction in other forums is permitted, provided the original author $(s)$ and the copyright owner(s) are credited and that the original publication in this journal is cited, in accordance with accepted academic practice. No use, distribution or reproduction is permitted which does not comply with these terms. 